Szegedi Tudományegyetem, Fogorvostudományi Kar Orális Medicina Részleg*

Szegedi Tudományegyetem, Fogorvostudományi Kar Szájsebészeti Tanszék**

Szegedi Tudományegyetem, Általános Orvostudományi Kar; Orvosi Informatikai Intézet ${ }^{\star \star *}$

\title{
A Szegedi Fogászati és Szájsebészeti Klinika orális és maxillofaciális régió onkológiai és egyéb betegségeinek retrospectív szúrési és epidemiológiai vizsgálata (1960-2014)
}

DR. SONKODI ISTVÁN*, DR. NAGY JUDIT*, DR. NOVÁK PÉTER*, DR. VIRÁG KATALIN**, DR. BODA KRISZTINA ${ }^{\star \star *}$, DR. BRAUNITZER GÁBOR**, DR. NAGY KATALIN**

\begin{abstract}
A Szegedi Fogászati és Szájsebészeti Klinika orális medicina szakrendelése az 1960-2014 időszakban 3 megye (átlagosan 1,7 millió fó) sztomato-onkológiai betegeinek ellátásáért volt felelős. Jelen közlemény a nevezett időszakban az orális medicina tárgykörébe foglalt betegségek incidencia-adatait összegzi. A vizsgált időszakban az összes új betegszám (ide értve a klasszikus értelemben vett stomatologiai betegeket) 338200 volt. Ebből az összesített esetszámból 9482 esetben jelentkeztek betegek jóindulatú szájüregi daganattal (2.8\%), 5438 esetben szájüregi precarcinomával (1.6\%), és 5145 esetben rosszindulatú szájüregi daganattal (1.5\%). Ilyen módon az 54 év összegzett daganatos és premalignus esetszáma 20 065-nek adódott, ami az összes új betegszám 5,9\%-a. Az előbbiek alapján a praemalignus és malignus léziók együttesen a sztomato-onkológiai incidenciának több mint felét adták, az összes új betegszámnak pedig 3,1\%-át. Az egyéb szájnyálkahártya-betegségekről 1974 óta vannak adataink. Az 1974-2014 időszakban 14446 új beteg jelentkezett ilyen betegségekkel (az erre az időszakra vetített incidencia 5,8\%-a). Az adott évben sztomato-onkológiai gondozásra visszarendelt betegekről 1970 óta vannak adataink, az 1970-2014 időszakban ezen betegek száma 117268 volt, ez az szakrendelés összes betegforgalmának 76,97\%-a.

A tendenciákra jellemző, hogy az 1960-tól 2004-ig tartó - reprezentatívnak tartott - időszakban az új jóindulatú daganatok száma tizenötszörösére, a precarcinomás esetek száma harmincszorosára, a rosszindulatú daganatok száma huszonötszörösére emelkedett, míg az egyéb szájnyálkahártya-betegségek száma ebben az időszakban a tizennégyszeresére nőtt.
\end{abstract}

Kulcsszavak: orális medicina, stomatoonkológia, incidencia, Dél-Magyarország

\section{Bevezetés}

Epidemiológiai vizsgálatok azt mutatják, hogy a szájüregi rákok gyakorisága a földrajzi elhelyezkedéstől függően változik [45].

Nemzetközi összehasonlításban is a szájüregi daganatok incidenciájában és mortalitásában Magyarország még az egyébként magas halálozást mutató szomszédos közép-kelet-európai országokhoz hasonlítva, valamint más megbízható adatszolgáltatással rendelkező 40-50 országot is figyelembe véve a legmagasabb értéket mutatta, és a drámaian emelkedő tendencia vonatkozásában is vezető helyre került [21, 29, 32].

A különböző stomatoonkológiai betegségek hazai szelektált és nem szelektált populáción végzett szürővizsgálati eredményeiről már több szerző is beszámolt [1-3, 8, 11, 13-15, 20, 28, 41-43].

Ilyen irányú onko-epidemiológiai ismereteink bővültek, de még mindig kiegészíthetők hézagpótló, ösz- szehasonlításra alkalmas újabb vizsgálatok eredményeivel.

Klinikánkon szervezett sztomato-onkológiai munka 1968-ban kezdődött, amikor az Országos Onkológiai Munkaértekezlet a szájüregi és arctájéki daganatok ellátását a stomatológiai szakhálózat körébe rendelte [27]. Ezt követően 1973-ban kiadták az első módszertani levelet, amely szervezési és szakmai irányelvek alapján kijelölte az egész országot lefedő és ellátó sztomato-onkológiai decentrumokat [17]. Klinikánk mint a sztomato-onkológiai centrumok egyike, kezdettől bekapcsolódott a szelektált és nem szelektált beteganyagon végzett, szervezett és alkalomszerú szürésekbe [35-38], daganatgyógyításba, rehabilitációba és gondozásba. Ezúttal kiemelten és elsődlegesen a több mint fél évszázados szürési és epidemiológiai tevékenységünk és eredményeink bemutatása a fő célunk, különös tekintettel az incidenciai adatokra, azaz az új esetek számának alakulására. 
A maxillo-facialis és az oropharyngealis régió az onkológiai betegségek korai felismerése és kezelése szempontjából a leginkább hozzáférhető, ezért felfedésükre javasolt és ígéretes törekvésnek számít az alkalomszerü szürővizsgálatok végzése annak ellenére, hogy a lakosságnak csupán 50\%-a keresi fel rendszeresen fogorvosát. Az is szomorú tény, hogy a szájüregi rákos betegek $60 \%$-a késői stádiumban, már metasztázisokkal, rossz kórjóslattal kerül észlelésre.

$A z$ orális és maxillofacialis régió onkológiai betegségeinek prevalenciájával, incidenciájával, morbiditásával és mortalitásával számos külföldi szerző foglalkozott [5, 7, 18, 23, 26, 34]. Világszerte jelentős azon publikációk száma is, amelyek az előbbi epidemiológiai vizsgálatok mellett különös figyelmet fordítottak a szekunder prevenciót szolgáló szervezett és alkalomszerü (opportunisztikus) szúrések hatékonyságának bemutatására [16, 19, 22 , 25, 33, 39, 44]. Tanulmányunkban egyéb szürési módszerek eredményeinek ismertetése mellett arra törekszünk, hogy az elsősorban alkalomszerű szűrésből származó eredményeinket összehasonlítsuk az alapul szolgáló külföldi vizsgálatokkal [24, 44].

\section{Anyag és Módszer}

A SZOTE Fogászati és Szájsebészeti Klinikájához mint központilag kijelölt sztomato-onkológiai decentrumhoz három megye (Bács-Kiskun, Békés és Csongrád) tartozik, átlag 1,7 millió népességgel (KSH).

Klinikánkon szelektált rizikócsoportokon (textil-, kendergyári és paprikafeldolgozó munkások), 2124 személyen, szervezett multifázisos (caries, parodontológiai, stomato-onkológiai) szűrések keretében végzett vizsgálatok az 1970-től 1973-ig terjedő időben történtek [36, 38].

Első, 1960-1974 között retrospectív szelektált és nem szelektált egyéneken végzett stomato-onkológiai szürővizsgálatunkat [37] 80269 új klinikai járóbetegen végeztük.

Továbbiakban már közöltünk adatokat 1960-tól 1974ig terjedő retrospektív szürővizsgálatról [35] szelektált és nem szelektált egyének esetében, különös tekintettel a praecarcinomára. A fenti időben klinikánkon 80269 új beteget jegyeztek be a járóbeteg rendelésen.

Klinikánk új járóbeteg forgalma 1960 és 2014 között 338200 beteg volt, amely magába foglalja a spontán jelentkező és az alapellátásból klinikánkra irányított fogászati és szájsebészeti betegeket, valamint a vonzáskörbe tartozó három megyéből küldött sztomato-onkológiai betegeket.

A későbbi tudományos célú deszkriptív és analitikus epidemiológiai vizsgálatok és a korán felismert fontosságú, klinikai hátterű rákregiszter („,hospital based cancer registry") kialakítása céljából minden sztomato-onkológiai beteg jelentkezésekor 1968 óta kitöltünk egy általunk összeállított és bevezetett számítógépes, epidemiológiai szempontból (kor, nem, lokalizáció, etiológia, kezelés, szövettan stb.) feldolgozásra és nyilvántartásra alkalmas, kódolt adatlapot. Az adatlapok számítógépes feldolgozása 1974 óta folyik, az adatokat először lyukkártyán és lyukszalagon, majd merevlemezen tárol- tuk. Ezt követően az esetek többségében fotót készítünk dokumentálás céljából, majd szükség esetén próbakimetszést végzünk a további kezelést meghatározó klinikopathológiai diagnózishoz. Minden szövettanilag igazolt praemalignus és malignus elváltozással bíró beteget 6 hónaponként ellenőrizzük és a meg nem jelenteket kiértesítjük, szigorú utánkövetést végezve.

A szájüregi és maxillofacialis onkológiai és egyéb szájbetegségeket döntően a WHO nomenklatúrája és klaszszifikációja alapján osztályoztuk, de amellett figyelembe vettük a Nemzetközi Rákkutató Ügynökség (IACR), a Nemzetközi Rákellenes Unió (UICC) és az Európai Unió (EU) ajánlásait [4, 46-49].

Jelen deszkriptív epidemiológiai munkánkban az orális medicinába tartozó betegségek incidenciájával foglalkoztunk a külföldi publikációk [6, 24, 31] eredményeivel való összehasonlításban, alapul véve az ilyen betegségek klasszifikációját [10].

A szájüregi daganatos és egyéb szájbetegségek incidenciáját 1960-2014 közötti időszakra az Orális Medicina részlegen megjelent 338200 új betegre számítottuk. Az adott időszakban külön elemeztük a jóindulatú, precancerosus és rosszindulatú elváltozások számának évenkénti változását azzal a céllal, hogy az incidencia alakulását is vizsgáljuk. Valamennyi elváltozás incidenciáját a klinikán megjelent új betegek számához viszonyítva határoztuk meg, éves lebontásban. A leíró statisztikai számításokon felül lineáris regressziós analízist végeztünk az incidencia változásának bemutatására. A statisztikai számításokhoz az SPSS 17.0 (IBM, USA) programot használtuk. A grafikonokat a SigmaPlot (Systat Software, Inc., USA) programmal készítettük.

Magyarországon az 1973-ban megjelent sztomatoonkológiai módszertani levél meghatározza, felsorolja és felhívja a figyelmet mindazon tünetekre, amelyek az orális és maxillofaciális régióban onkológiai elváltozásra utalnak. Egyéb teendők mellett hangsúlyozza, hogy a fogászati alapellátást végző és praktizáló fogorvosok kötelesek az egyéb fogászati panaszokkal jelentkező biztosítottaknál a később jogszabályban is (48/1997. [XII.17.] NM. rend.) előírt sztomato-onkológiai alkalomszerü (opportunisztikus) szűrővizsgálatot elvégezni és az így kiszűrt beteget az egyetemi - kiemelt szintű - ellátást (kivizsgálás, kezelés, gondozás) végző Konzultációs Bizottsághoz irányítani. A háziorvosok ajánlottan végeznek alkalomszerüen - ad hoc sztomato-onkológiai szúrést [12].

Klinikánkon az 1970-es évek óta a fogorvosok, de általános orvosok alap- és továbbképzésében az orális medicina és stomatologia tantárgyon belül mind elméletben, mind gyakorlatban megkülönböztetett figyelmet fordítunk az orális és maxillofaciális onkológiai betegségek felismerésének elsajátítására és diagnosztizálására, ami elfogadható alapot szolgáltat az alkalomszerü, szükség szerint célzott szürések végzéséhez.

Vizsgálatunkban egyrészt szeretnénk röviden kitérni a klinikánkon mint központilag kijelölt sztomato-onkológiai decentrumban 1960 és 2014 között végzett munká- 
ra, másrészt összehasonlításra alkalmas bővebb morbiditási adatokkal szolgálni a szájüregi rákos epidemiológiát. Az utóbbi vonatkozásában csupán az 1973-tól 2004-ig tartó időbeli eredményeket tekintjük reprezentatívnak, a fennmaradó időben klinikánkon több okból bekövetkezett betegforgalmi változások miatt.

\section{Eredmények}

Szelektált rizikócsoporton végzett, szervezett multifázisos (caries, parodontológia, sztomato-onkológia) szúréssel [38] a 2124 megvizsgált személyen 103 esetben fedeztünk fel sztomato-onkológiai betegséget, ami 2,4\%-ban (51 eset) praecarcinomának bizonyult, rosszindulatú daganat nem volt.

Az 1960-1974 év között szelektált és nem szelektált egyéneken végzett retrospektív vizsgálatunkban $[35,37]$ a klinikánk 80269 új beteg közül összesen 1372 sztomato-onkológiai beteget $(1,70 \%)$ szürtünk ki, amiből 575 eset $(0,71 \%)$ jóindulatú tumornak, 239 eset $(0,29 \%)$ praecarcinomának és 218 eset $(0,27 \%)$ rosszindulatú daganatnak bizonyult. Tehát a praecarcinomák és a rosszindulatú daganatok együttes előfordulási aránya 0,569\% volt.

Jelen, 1960 és 2014 közötti retrospektív feldolgozásunkban összesen 338200 új járóbeteg jelentkezett klinikánkon, amiből 20065 beteg (5,93\%) volt jó-, premalignus-, és rosszindulatú betegségben szenvedő, és 14446 beteg $(5,80 \%)$ pedig egyéb szájnyálkahártyabetegségekben, ami így együtt 34511 beteget $(10,2 \%)$ jelentett. Ezen belül $9482(2,80 \%)$ jóindulatú daganat, $5438(1,60 \%)$ praecarcinoma és $5145(1,50 \%)$ rosszindulatú daganat fordult elő. Összesen 10579 praecarcinomás és carcinomás beteget észleltünk, ami 3,1\%-os incidenciának felel meg (I. táblázat).

Amennyiben az adatokat évtizedekre lebontva vizsgáljuk (II. táblázat), kitűnik, hogy 1969-ig klinikánk főleg jóindulatú maxillo-facialis tumoros beteget fogadott és kezelt, és csak kevés számú praecarcinomát és malignus tumort láttunk el (341 jóindulatú daganat $(0,61 \%)$, 88 praecarcinoma $(0,15 \%), 65$ rosszindulatú daganat $(0,12 \%))$. Amint a táblázat mutatja, a következő évtizedben (19701979) a daganatos esetek száma ugrásszerű növekedést mutatott (mindhárom vizsgált elváltozástípusban), míg az összes új betegszám szinte változatlan maradt, tehát a daganatos esetek aránya nőtt. Az ezt követő két évtizedben az új esetek száma az 1970-es évekhez képest az 1980-as években 2-2,5-szeres növekedést mutatott, majd stagnált. Ennek helyes értelmezéséhez mindenképpen figyelembe kell venni azt is, hogy ezekben az évtizedekben az összes új betegszám valamelyest csökkent. A 2000-től 2009-ig terjedő időszakban összesen már 5338 új daganatos beteget regisztráltunk, ebből az esetszámból 2995 esetben lett jóindulatú daganat a diagnózis (3,88\%), 1422 esetben precarcinoma $(1,84 \%)$ és 921 esetben rosszindulatú daganat $(1,19 \%)$.

A vizsgált időszakban a daganatos és premalignus megbetegedések incidenciájának csúcsát az 1986-tól 2002-ig terjedő időszak jelenti. 1986-ban történt meg először, hogy a daganatos betegek a klinika új betegforgalmának több mint 10\%-át tették ki. Ezen időszakon belül is kiemelt az 1995-2002 intervallum, amelyen belül végig $20 \%$ közelében volt az új daganatos esetek aránya az összes új eseten belül. 1996 és 2000 negatív csúcsnak tekinthetők: ebben a két évben a daganatos és premalignus összes incidencia-arány a $30 \%$-ot közelítette, bár 1996, mint már említettük, jelentősen elmaradt a többi évtől az összes új betegszám tekintetében, tehát ebben az évben valószínúleg inkább egy relatív növekedésről beszélhetünk.

A táblázatokat áttekintve kétféle tendencia is világosan látszik: egyfelől mindhárom vizsgált elváltozástípus incidenciája monoton, szignifikáns növekedést mutatott a vizsgált időszakban. Jóindulatú daganatok esetében: $(\beta=0,97, t(51)=28,21, p<0,001)$, premalignus elváltozásoknál $(\beta=0,87, t(51)=12,43, p<0,001)$ és rosszindulatú daganatoknál is $(\beta=0.44, t(51)=3,45, p<$ $0,001)$. Értelemszerüen az összes daganatos incidencia is szignifikáns növekedést mutatott $(\beta=0,91, t$ (51) $=15,03, p<0.001)$. A másik szembetúnő tendencia, hogy a vizsgált elváltozástípusok incidenciájának aránya a vizsgált időszakban nem mutatott jelentős változást. Ezek a tendenciák az 1. ábrán jól követhetők.

Az adatokat áttekintve az mondható el, hogy 1960 és 2014 között mindhárom vizsgált elváltozástípus incidenciája töretlen növekedést mutatott, még úgy is, ha figyelembe vesszük, hogy 2004 után klinikánk a rosszindulatú betegségek ellátásáért csak megosztottan volt felelős.

Az 1960-2004 időszakban az összes tumoros és premalignus esetszám az 1960-as években tapasztalható visszafogottabb növekedést követően (1960-ban 27 új eset, 1969-ben 80), az 1970-es években egy nagyságrenddel növekedett (ekkor évente 100 új eset alatt már nem regisztráltunk), az általunk észlelt csúcsot pedig az 1990-es években érte el, amikor évi 600 új eset is előfordult. Az 1960-tól 2004-ig tartó időszakban a jóindulatú daganatok száma tizenötszörösére, a precarcinomás esetek száma harmincszorosára, a rosszindulatú daga-

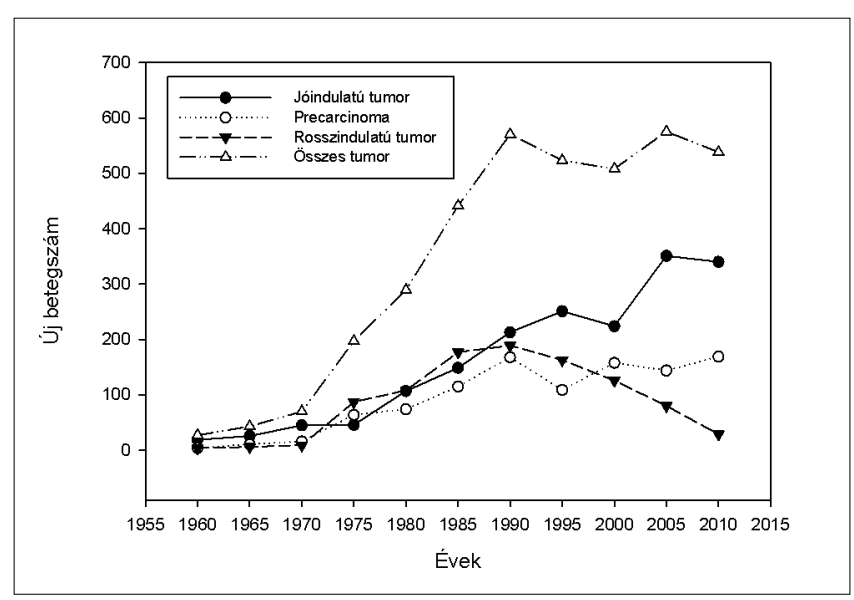

1. ábra: Az orális és maxillofaciális régiót érintő jó-, premalignus-, és rosszindulatú betegségek incidenciájának megoszlása ötéves bontásban 
Orális és maxillofaciális onkológiai és szájbetegségek incidenciája 1960-2014.

\begin{tabular}{|c|c|c|c|c|c|c|c|}
\hline Év & $\begin{array}{c}\text { A klinika } \\
\text { új betegforgalma } \\
\text { (fö) }\end{array}$ & $\begin{array}{l}\text { Adott évben } \\
\text { kontrollra } \\
\text { érkezett } \\
\text { (fő) }\end{array}$ & $\begin{array}{c}\text { Jóindulatú } \\
\text { tumor } \\
\text { (esetszám) }\end{array}$ & $\begin{array}{c}\text { Prae- } \\
\text { carcinoma } \\
\text { (esetszám) }\end{array}$ & $\begin{array}{c}\text { Rosszindulatú } \\
\text { tumor } \\
\text { (esetszám) }\end{array}$ & $\begin{array}{c}\text { Összes tumor } \\
\text { (\% az összes } \\
\text { új beteghez } \\
\text { viszonyítva) }\end{array}$ & $\begin{array}{c}\text { Szájbetegség } \\
\text { (\% az összes } \\
\text { új beteghez } \\
\text { viszonyítva) }\end{array}$ \\
\hline 1960 & 5338 & - & 19 & 4 & 4 & $27 \quad(0,51 \%)$ & - \\
\hline 1961 & 5227 & - & 27 & 5 & 3 & $35 \quad(0,67 \%)$ & - \\
\hline 1962 & 5402 & - & 39 & 7 & 1 & $47 \quad(0,87 \%)$ & - \\
\hline 1963 & 6023 & - & 34 & 6 & 4 & $44 \quad(0,73 \%)$ & - \\
\hline 1964 & 5972 & - & 33 & 6 & 3 & $42 \quad(0,70 \%)$ & - \\
\hline 1965 & 5318 & - & 26 & 11 & 6 & $43 \quad(0,81 \%)$ & - \\
\hline 1966 & 5721 & - & 35 & 8 & 5 & $48 \quad(0,84 \%)$ & - \\
\hline 1967 & 6112 & - & 30 & 12 & 7 & $49 \quad(0,80 \%)$ & - \\
\hline 1968 & 5416 & - & 52 & 15 & 12 & $79 \quad(1,46 \%)$ & - \\
\hline 1969 & 5318 & - & 46 & 14 & 20 & $80 \quad(1,50 \%)$ & - \\
\hline 1970 & 6014 & 16 & 45 & 16 & 9 & $70 \quad(1,16 \%)$ & - \\
\hline 1971 & 6268 & 81 & 29 & 8 & 19 & $56 \quad(0,89 \%)$ & - \\
\hline 1972 & 5743 & 715 & 44 & 36 & 20 & $100 \quad(1,74 \%)$ & - \\
\hline 1973 & 5777 & 2167 & 74 & 41 & 41 & $156 \quad(2,70 \%)$ & - \\
\hline 1974 & 5052 & 2062 & 42 & 50 & 64 & $156 \quad(3,09 \%)$ & $33 \quad(0,65 \%)$ \\
\hline 1975 & 4602 & 887 & 46 & 64 & 87 & $197 \quad(4,28 \%)$ & $61 \quad(1,33 \%)$ \\
\hline 1976 & 5371 & 1620 & 98 & 62 & 107 & $267 \quad(4,97 \%)$ & $166 \quad(3,09 \%)$ \\
\hline 1977 & 6287 & 4982 & 105 & 94 & 94 & $293 \quad(4,66 \%)$ & $220 \quad(3,50 \%)$ \\
\hline 1978 & 6325 & 1965 & 113 & 76 & 136 & $325 \quad(5,14 \%)$ & $193 \quad(3,05 \%)$ \\
\hline 1979 & 5974 & 2162 & 82 & 83 & 108 & $273 \quad(4,57 \%)$ & $162(2,71 \%)$ \\
\hline 1980 & 5439 & 2483 & 107 & 74 & 108 & $289 \quad(5,31 \%)$ & $171 \quad(3,14 \%)$ \\
\hline 1981 & 4859 & 2290 & 113 & 81 & 115 & 309 (6,36\%) & $175 \quad(3,60 \%)$ \\
\hline 1982 & 5275 & 2842 & 131 & 85 & 147 & $363 \quad(6,88 \%)$ & $206 \quad(3,91 \%)$ \\
\hline 1983 & 5081 & 2663 & 136 & 90 & 171 & $397 \quad(7,81 \%)$ & $192(3,78 \%)$ \\
\hline 1984 & 5060 & 2676 & 196 & 113 & 182 & $491 \quad(9,70 \%)$ & $182(3,60 \%)$ \\
\hline 1985 & 4751 & 2767 & 149 & 115 & 177 & $441 \quad(9,28 \%)$ & $196 \quad(4,13 \%)$ \\
\hline 1986 & 4678 & 2951 & 179 & 132 & 223 & $534(11,42 \%)$ & $254 \quad(5,43 \%)$ \\
\hline 1987 & 4614 & 2002 & 136 & 144 & 218 & $498(10,79 \%)$ & $243 \quad(5,27 \%)$ \\
\hline 1988 & 4943 & 2585 & 228 & 178 & 212 & $618(12,50 \%)$ & $301 \quad(6,09 \%)$ \\
\hline 1989 & 4458 & 2520 & 210 & 166 & 186 & $562(12,61 \%)$ & $341 \quad(7,65 \%)$ \\
\hline 1990 & 3944 & 2552 & 213 & 168 & 189 & $570(14,45 \%)$ & $278 \quad(7,05 \%)$ \\
\hline 1991 & 5348 & 3217 & 220 & 190 & 190 & $600(11,22 \%)$ & $308 \quad(5,76 \%)$ \\
\hline 1992 & 3974 & 3274 & 190 & 191 & 164 & $545(13,71 \%)$ & $283 \quad(7,12 \%)$ \\
\hline 1993 & 4143 & 2974 & 214 & 176 & 166 & $556(13,42 \%)$ & $309 \quad(7,46 \%)$ \\
\hline 1994 & 3991 & 2992 & 238 & 134 & 151 & $523(13,10 \%)$ & $340 \quad(8,52 \%)$ \\
\hline 1995 & 2879 & 2866 & 251 & 109 & 163 & $523(18,17 \%)$ & $335(11,46 \%)$ \\
\hline 1996 & 1799 & 3062 & 227 & 113 & 156 & $496(27,57 \%)$ & $406(22,57 \%)$ \\
\hline 1997 & 1815 & 3218 & 238 & 92 & 146 & $476(26,23 \%)$ & $437(24,08 \%)$ \\
\hline 1998 & 2037 & 2859 & 213 & 110 & 156 & $479(23,51 \%)$ & $432(21,21 \%)$ \\
\hline 1999 & 2024 & 2455 & 230 & 141 & 130 & $501(24,75 \%)$ & $369(18,23 \%)$ \\
\hline 2000 & 1846 & 2355 & 224 & 158 & 126 & $508(27,52 \%)$ & $360(19,50 \%)$ \\
\hline 2001 & 2083 & 2197 & 244 & 129 & 129 & $502(24,10 \%)$ & $393(18,87 \%)$ \\
\hline 2002 & 2709 & 2515 & 284 & 119 & 128 & $531(19,60 \%)$ & $427(15,76 \%)$ \\
\hline 2003 & 5525 & 2454 & 282 & 116 & 104 & $502 \quad(9,09 \%)$ & $443 \quad(8,02 \%)$ \\
\hline 2004 & 7368 & 2629 & 281 & 119 & 99 & $499(6,77 \%)$ & $468 \quad(6,35 \%)$ \\
\hline 2005 & 5678 & 2932 & 351 & 144 & 80 & $575(10,13 \%)$ & $486 \quad(8,56 \%)$ \\
\hline 2006 & 11747 & 3294 & 274 & 148 & 59 & $481 \quad(4,09 \%)$ & $445 \quad(3,79 \%)$ \\
\hline 2007 & 12678 & 3054 & 307 & 163 & 93 & $563 \quad(4,44 \%)$ & $455 \quad(3,59 \%)$ \\
\hline
\end{tabular}




\begin{tabular}{|c|c|c|c|c|c|c|c|}
\hline Év & $\begin{array}{c}\text { A klinika } \\
\text { új betegforgalma } \\
\text { (fó) }\end{array}$ & $\begin{array}{c}\text { Adott évben } \\
\text { kontrollra } \\
\text { érkezett } \\
\text { (fó) }\end{array}$ & $\begin{array}{c}\text { Jóindulatú } \\
\text { tumor } \\
\text { (esetszám) }\end{array}$ & $\begin{array}{c}\text { Prae- } \\
\text { carcinoma } \\
\text { (esetszám) }\end{array}$ & $\begin{array}{c}\text { Rosszindulatú } \\
\text { tumor } \\
\text { (esetszám) }\end{array}$ & $\begin{array}{c}\text { Összes tumor } \\
\text { (\% az összes } \\
\text { új beteghez } \\
\text { viszonyítva) }\end{array}$ & $\begin{array}{c}\text { Szájbetegség } \\
\text { (\% az összes } \\
\text { új beteghez } \\
\text { viszonyítva) }\end{array}$ \\
\hline $\mathbf{2 0 0 8}$ & 15230 & 3372 & 353 & 165 & 70 & $588(3,86 \%)$ & $625(4,10 \%)$ \\
\hline $\mathbf{2 0 0 9}$ & 12245 & 3698 & 395 & 161 & 33 & $589(4,81 \%)$ & $619(5,06 \%)$ \\
\hline $\mathbf{2 0 1 0}$ & 10754 & 3687 & 340 & 169 & 29 & $538(5,00 \%)$ & $693(6,44 \%)$ \\
\hline $\mathbf{2 0 1 1}$ & 10049 & 3480 & 338 & 167 & 26 & $531(5,28 \%)$ & $574(5,71 \%)$ \\
\hline $\mathbf{2 0 1 2}$ & 9828 & 3430 & 323 & 181 & 31 & $535(5,44 \%)$ & $598(6,08 \%)$ \\
\hline $\mathbf{2 0 1 3}$ & 9960 & 2993 & 333 & 151 & 22 & $506(5,08 \%)$ & $604(6,06 \%)$ \\
\hline $\mathbf{2 0 1 4}$ & 18748 & 3273 & 315 & 128 & 16 & $459(2,45 \%)$ & $663(3,54 \%)$ \\
\hline $\begin{array}{c}\text { Összesen } \\
\mathbf{1 9 6 0 -}\end{array}$ & 338200 & - & 9482 & 5438 & 5145 & 20065 & - \\
\hline $\begin{array}{c}\text { Összesen } \\
\mathbf{1 9 7 4 -}\end{array}$ & 251171 & 117268 & $(2,8 \%)$ & $(1,6 \%)$ & $(1,5 \%)$ & $(5,9 \%)$ & - \\
\hline
\end{tabular}

Magyarázat: a szájbetegségek számáról 1974-től kezdődően állnak rendelkezésre adatok, ezért az adatokat 1960-tól és 1974-től kezdődően külön összesítettük (illetve a kontrollra érkezett betegek számát 1970-től). A klinika új betegforgalma alatt a spontán jelentkező vagy beutalt fogászati-, szájsebészeti-, sztomato-onkológiai és szájnyálkahártya betegségekkel érkező új betegek számát értjük. Ebből jelen táblázatban csak a daganatos és egyéb szájbetegségek kerülnek részletezésre.

II. táblázat

Incidencia-adatok évtizedenkénti lebontásban

(zárójelben az összes új betegszámhoz viszonyított százalékos arány)

\begin{tabular}{|c|c|c|c|c|c|}
\hline Évtized & Összes új betegszám & Összes tumor & Benignus tumor & Precarcinoma & Malignus tumor \\
\hline $1960-1969$ & 55847 & $494(0,88 \%)$ & $341(0,61 \%)$ & $88(0,16 \%)$ & $65(0,12 \%)$ \\
\hline $1970-1979$ & 57413 & $1893(3,29 \%)$ & $678(1,18 \%)$ & $530(0,92 \%)$ & $685(1,19 \%)$ \\
\hline $1980-1989$ & 49158 & $4502(9,16 \%)$ & $1585(3,22 \%)$ & $1178(2,40 \%)$ & $1739(3,54 \%)$ \\
\hline $1990-1999$ & 31954 & $4768(14,92 \%)$ & $2234(6,99 \%)$ & $1424(4,46 \%)$ & $1611(5,04 \%)$ \\
\hline $2000-2009$ & 77109 & $5338(6,92 \%)$ & $2995(3,88 \%)$ & $1422(1,84 \%)$ & $921(1,19 \%)$ \\
\hline
\end{tabular}

natok száma huszonötszörösére emelkedett. Az adott időszakban a kontrollra visszajáró (gondozott) betegek összes száma 117268 fő volt, ez a szakrendelés öszszes betegforgalmának $76,97 \%$-a volt.

\section{Megbeszélés}

1968-ig klinikánkon főleg jóindulatú tumoros beteget kezeltek, csak kevés számú praecarcinomás és malignus tumor került ellátásra az Intézet személyi-, és tárgyi feltételeinek hiányában.

Hazánkban rizikócsoportokon végzett vizsgálatokban [13, 36, 38, 41] a szájüregi praecarcinomák és carcinomák átlagos incidenciája magasabb volt $(7,96 \%)$, mint a normál populáción közölt korábbi [1-3, 8, 15, 20, $35,37]$ és a jelen munka eredményei, amely csupán 3,1\%-nak mutatkozott. Szabó és mtsai. [41] hajléktalanokon végzett szelektív szürés során magas, 19,33\%os értékról számoltak be, igazolva a rizikócsoportokon végzett szürések prioritását.

A rizikócsoportos magyarországi adataink közel hasonlóak a külföldi ilyen irányú vizsgálatokhoz $[25,30]$ és a normál populációs eredményekhez [7, 23, 34, 40], mert a rizikócsoportok esetében a szájüregi praecancerosisok és cancerosisok prevalenciája döntően $6 \%$ és $25 \%$ között, míg a nem rizikócsoportok között föleg $1 \%$ és $6 \%$ között változott. Rákregiszterünk klinikai adatbázisából származóan a jövőben publikálásra szánt analitikus vizsgálataink segíthetnek kijelölni a szürővizsgálati célcsoportokat, hozzájárulva a népesség szintű szűrővizsgálat szükséges bevezetésének megítéléséhez.

Megjegyeznénk, hogy az 1960-1974 közötti, a klinika beteganyagában feltárt [37] sztomato-onkológiai morbiditási 1,70\%-os arányt nem tekintjük jellemzőnek és öszszehasonlításra alapot szolgálónak, mert ezek az adatok olyan időszakra is vonatkoznak, amikor még ezekre az elváltozásokra nem fordítottunk olyan hangsúlyos figyelmet, mint a későbbiekben. Az adatok azonban így is rámutatnak a sztomato-onkológia fontosságára, kiemelve a fogorvos, orvos szerepét a rák megelőzésében és a szürések fontosságának bizonyításában.

A több mint ötven évet reprezentáló szájüregi praecarcinomákra és carcinomákra vonatkoztatott jelen 3,1\%os incidencia értékünk nem különbözött jelentősen K. Lim és mtsai. [24] által közölt 4,2\%-os ilyen irányú gyakoriságtól, csupán abban tért el, hogy az utóbbi prospektív alkalomszerű szűrésből származott. Carcinomák 
esetén saját vizsgálatunkban 5145 beteg (1,55\%) volt, míg a külföldiben csak 2 beteg $(0,08 \%)$

Az orális és maxillo-facialis tájéki onkológiai betegségek a jó hozzáférhetőségük és elhelyezkedésük miatt rövid idő alatt egyszerǔen és bonyolult, drága múszerezettség nélkül non-invazív módon könnyen diagnosztizálhatók, így már korai stádiumban felismerhetők és kedvezőbb eredménnyel kezelhetők, valamint a túlélési arány is javítható. Ez a körülmény hivatott alátámasztani és kétséget kizáróan megerősíteni a szekunder prevenció, vagyis a szürővizsgálatok fontosságát és bevezetésük indokoltságát.

Reméljük, hogy több mint félévszázados deszkriptív epidemiológiai vizsgálatunk hozzájárul ahhoz, hogy a korábban drámaian emelkedett, majd stagnáló hazai szájüregi rákelőfordulás és rákhalálozás csökkentése sürgető népegészségügyi feladattá váljon, és felhívja a figyelmet a szelektív és nem szelektív szűrővizsgálatok végzésének fontosságára. Longitudinális vizsgálatunk arra is alkalmas, hogy a szájüregi rák epidemiológiai adataival segít képet adni három dél-magyarországi megye érintettségéről, alapul szolgálva más hazai területeken ilyen irányú felmérések összehasonlítására, másrészt megkönnyíti azt az egészségpolitikai elhatározást, hogy az ország mely területein a legsürgetőbb javítani a helyzeten, például szűrések bevezetésével.

Az általános fogorvosi alapellátásban végzett prospektív [24] és saját retrospektív alkalomszerü szürési eredményeink azt igazolják, hogy a sztomato-onkológiában ez a módszer reális lehetőséggel kecsegtet populációs szűrések végzésében és a szájüregi rákok visszaszorításáért folytatott küzdelemben.

A külföldi prospektív [24] és a saját, jelen retrospektív, az általános fogászati alapellátásban kezelt és alkalomszerüen sztomato-onkológiailag „kiszürt” betegeken történő epidemiológiai felmérésünk reprezentatívnak tekinthető, mert visszatükrözi az általános populációban előforduló különböző típusú szájüregi onkológiai elváltozásokat és gyakoriságukat. Ezért az opportunisztikus szúrési módszer egy reális alternatívája lehet a lakossági tömegszürésnek, amelynek mielőbbi magyarországi elindítását tenné javasolttá, bár vannak olyan külföldi [22, 39, 44] és hazai [12] publikációk, amelyek a szájüregi rákok tömegszürését még nem tartják indokoltnak.

A több mint 50 évet átfogó epidemiológiai és szürési eredményeinkben a „kiszűrt” és megvizsgált 35247 betegen észleltünk egy vagy több, valamilyen szájnyálkahártya elváltozást, ami 12,06\% praevalenciát jelent. Ez az érték közel van a Bouguot [6] által 10,3\%-os és a Lim és mtsai. [24] által 14,1\%-os közölt adatokhoz, de az irodalomban előfordultak 3\%-os és $81 \%$-ig [9] terjedő magas százalékos eredmények is, jelezve az összehasonlítás nehézségeit, melyet az eltérő szűrési módszerek, populációs minták és klasszifikációbeli különbségek magyarázhatnak.

Van olyan közlemény [23], amely szerint az opportunisztikus tömegszűrés az egyedüli járható út a szájüregi praecarcinomák és carcinomák korai felismerésére és magas túlélési ráta elérésére. Tekintve, hogy tanulmányunkba a korábban jelzett három megye gyakorló fogorvosai és orvosai által sztomato-onkológiailag kiszürt és klinikánkra irányított betegeket vontuk be epidemiológiai feldolgozásunkba, ezért a tetemes számú betegen végzett retrospektív vizsgálatunk szervezett és opportunisztikus tömegszűrésnek, másrészt reprezentatívnak fogadható el, jelezve és megerősítve saját véleményünket e szűrési módszer előnyei és elsődleges alkalmazhatósága mellett. Jelen munkánk egyik fő célja, hogy elsősorban a fogorvosok figyelmét hívjuk fel arra a felelősségteljes szerepre, miszerint a fogászati panaszok ellátása mellett végezzék el a pár perces, félelmet, fájdalmat nem okozó, nem invazív és költségkímélő szájüregi rákszűrést, ezzel segítve a rák korai felismerését és javítva a rák jobb kezelési esélyeit, valamint csökkentve a mortalitást és elősegítve a jobb túlélési rátát. Ezért is fordítunk megkülönböztetett figyelmet a sztomato-onkológiai és egyéb szájbetegségek oktatására az alap- és továbbképzéseken.

Ahhoz, hogy a különböző szűrések hatékonysága fokozódjon, jelentős szemléletváltozásra lenne szükség, elsősorban a lakosság (tájékozatlanság, félelem a ráktól, kezeléstől), de munkáltatók (érdekviszonyok változása) részéről is. Így a szűrések hatékonyságának növeléséhez államilag támogatott lakossági rendszeres egészségpropagandára, nevelésre lenne szükség, valamint különböző engedményekkel segíteni a dolgozót a részvételben.

Reméljük, javít a helyzeten, hogy klinikánkon szervezett szűrés keretében a három megyéből „kiszűrt” és számítógépes nyilvántartásba vett, 1968 óta kezelt és utánkövetett betegekkel szolgálja a hazai primer, szekunder és tercier prevenciós célokat, mérsékelve a sztomato-onkológiai betegségek okozta halálozás növekvő trendjét.

\section{Köszönetnyilvánítás}

A szerzők köszönetet mondanak Dr. Buzás Kristófnak a kézirat szerkesztésében és Enginé Gyöngyösi Csillának az adatok bevitelében nyújtott segítségéért.

\section{Irodalom}

1. BAKó A, Kósa Zs: Szürővizsgálati modellprogram a szájüregi daganatok korai felismerésére Szabolcs-Szatmár-Bereg megyében Magyar Fogorvos, 2001(2001/4): 197-201.

2. BÁnÓCZY J, RADNAI T, REMÉnYI I: [Our methodologic experience in the stomatologic-oncologic mass screening of the population of Dunakeszi and Felsogod]. Fogorvosi szemle, 1969; 62(4): 118122.

3. Bánóczy J, Bosnyák M, Benyó A, Ludmány N, Rigó O, Árky Zs, Joó J: Tüdő-ernyőfényképszúrő szolgálathoz csatlakozó stomato-onkológiai szúrővizsgálatok tapasztalatai Budapest VI. kerületében. Magyar onkologia, 1990(34): 81-85.

4. Barnes LE, Reichart, PA, Sidransky, D: World Health Organisation Classification of Tumors. Pathology and Genetics. Head and neck Tumors. In: WHO, editor. IACR; Lyon 2005. 
5. Bosetti C, Bertuccio P, Levi F, Lucchini F, Negri E, La Vecchia C: Cancer mortality in the European Union, 1970-2003, with a joinpoint analysis. Ann Oncol, 2008; 19(4): 631-640.

6. Bouquot JE: Common oral lesions found during a mass screening examination. J Am Dent Assoc, 1986; 112(1): 50-57.

7. Boyle P, Ferlay J: Cancer incidence and mortality in Europe 2004. Ann Oncol, 2005; 16(3): 481-488.

8. Bruszt P: [Stomato-oncological screening tests in 7 villages of the Baja and Bacsalmas district]. Magyar onkologia, 1962; 6: 28-33.

9. CAmpisi G, Margiotta V: Oral mucosal lesions and risk habits among men in an Italian study population. J Oral Pathol Med, 2001; 30(1): 22-28.

10. Carpenter WM, Jacobsen PL, Eversole LR: Two approaches to the diagnosis of lesions of the oral mucosa. $J$ Calif Dent Assoc 1999; 27(8): 619-624.

11. Csépe P, BÁnóczy J, Dombi C, ForRal J, Gyenes M, Döbrössy L: [Model program for screening oral cancers in the Roma population]. Magyar onkologia, 2007; 51(2): 95-101.

12. DöвRössy L: A szájüregi daganatok epidemiológiája: a probléma jelentősége. Magyar onkologia, 2001; (45): 99-105.

13. Dombı C, Vörös-Balog T, Czeglédy A, Hermann P, Vincze N, BáNÓczY J: Risk group assessment of oral precancer attached to X-ray lung-screening examinations. Comm Dent Oral Epid, 2001; 29(1): 9-13.

14. DomBI Cs, Czeglédy A, BÁNóczY J: Tüdő-ernyőképszűrő szolgálathoz kapcsolódó stomato-onkológiai vizsgálatok. Magyar onkologia, 1995; (39): 194.

15. Dombı Cs Vörös-Balog T, Vincze N, Bánóczy, J: A Budapest III. kerületében végzett stomato-onkológiai szürővizsgálat tapasztalatai. Lege Artis Medicinae, 1996; 6: 728-733.

16. Downer MC, Moles DR, Palmer S, Speight PM: A systematic review of measures of effectiveness in screening for oral cancer and precancer. Oral Oncol, 2006; 42(6): 551-560.

17. EgÉSZsÉGÜGYI MıNISZTÉRIUM: Stomato-onkológiai módszertani levél. Budapest, 1973.

18. Ferlay JB, F Pisani, P, et al.: GLOBOCAN 2000: Cancer incidence, mortality and prevalence worldwide. In: 5. ICBN, editor. Lyon, 2002

19. Gupta PC, Mehta FS, Pindborg JJ, Bhonsle RB, Murti PR, Daftary DK, et al.: Primary prevention trial of oral cancer in india: a 10-year follow-up study. J Oral Pathol Med, 1992; 21(10): 433-439.

20. Kardos L, Pácz M, Reményı I, Nemes I: [Stomato-oncological screening test of volunteers]. Magyar onkologia, 2000; 44(2): 145-147.

21. KÁSLER M, OtTó S: [Secondary prevention and early detection (screening) of malignant tumors]. Orv Hetil, 1993; 134(9): 473-480.

22. Kujan O, Glenny AM, Oliver RJ, Thakker N, Sloan P: Screening programmes for the early detection and prevention of oral cancer. Cochrane Database Syst Rev, 2006; (3): CD004150.

23. La Vecchia C, Lucchini F, Negri E, LeVI F: Trends in oral cancer mortality in Europe. Oral Oncol, 2004; 40(4): 433-439.

24. Lim K, Moles DR, Downer MC, SPEIGHT PM: Opportunistic screening for oral cancer and precancer in general dental practice: results of a demonstration study. Br Dent J, 2003; 194(9): 497-502.

25. Mehta FS, Gupta PC, Daftary DK, Pindborg JJ, Choksi SK: An epidemiologic study of oral cancer and precancerous conditions among 101,761 villagers in Maharashtra, India. Int J Cancer, 1972; 10(1): 134-141

26. Moore SR, Johnson NW, Pierce AM, Wilson DF: The epidemiology of mouth cancer: a review of global incidence. Oral Dis, 2000; 6(2): 65-74.

27. OnKológial munKá́RTEKEZLEt. Magyar onkologia, 1979; 13(57).
28. Orosz M, DivinYI T: [Incidence of benign soft tissue tumors in the oral cavity, based on the analysis of 306 cases]. Fogorvosi szemle, 1976; 69(3): 69-72.

29. Otтó S, KÁsLeR M: Rákmortalitás és -incidencia hazánkban, az európai adatok tükrében. Magyar onkologia, 2002; (46): 111-117.

30. Pearson N, Croucher R, Marcenes W, O'Farrell M: Prevalence of oral lesions among a sample of Bangladeshi medical users aged 40 years and over living in Tower Hamlets, UK. Int Dent J, 2001; 51(1): 30-34.

31. Reichart PA: Oral mucosal lesions in a representative crosssectional study of aging Germans. Comm Dent Oral Epid, 2000; 28(5): 390-398.

32. RemenÁR E: [Proposal for screening of oral and oropharyngea cancer in the population at risk]. Magyar onkologia, 2001; 45(2): 149-151.

33. Sankaranarayanan R, Ramadas $\mathrm{K}$, Thomas $\mathrm{G}$, Muwonge R, Thara $\mathrm{S}$ MATHEW $B$, et al.: Effect of screening on oral cancer mortality in Kerala, India: a cluster-randomised controlled trial. Lancet, 2005; 365(9475): 1927-1933.

34. Silverman S, JR.: Demographics and occurrence of oral and pharyngeal cancers. The outcomes, the trends, the challenge. J Am Dent Assoc, 2001; 132 Suppl, 7S-11S.

35. SonKod I, Boda K: [Precancerous lesions of the oral cavity with special reference to white lesions]. Fogorvosi szemle, 1977; 70(9): 257-262.

36. Sonkodı I, Tо́тн K: A szegedi textilipari munkások stomato-onkológiai vizsgálata. Fogorvosi szemle, 1972; (65): 560-509.

37. Sonkodı I, Gorzó I, Borbéty L, Tátrai J, Boda K: A Szegedi Fogászati és Szájsebészeti Klinika sztomato-onkológiai beteganyagának számítógépes feldolgozása 1960-1974 között. Árkövy Kongresszus; Pécs, 1977

38. SONKODI I, TóTH K: Újabb adatok szegedi ipari munkások stomatoonkológiai vizsgálatáról. Népegészségügy, 1975; (56): 282-284.

39. SpEIGHT PM DM, ZAKRZEWSKA J: Screening for oral cancer and precancer. A report of the UK working group on screening for oral cancer and precancer. Community dental health, 1993; (10): 1-89.

40. Speight PM, ZaKRZEWSKA J, Downer MC: Screening for oral cancer and precancer. Eur J Cancer Part B, Oral oncology, 1992; 28B(1): 45-48.

41. Szabó G, KlenK G, VeÉr A: [Correlation between the combination of alcohol consumption and smoking in oral cancer (screening of the population at risk)]. Orv Hetil, 1997; 138(52): 3297-3299.

42. VÁmos I, Orosz M, Csiba A: [Incidence of tumors of the face, jaw and oral cavity]. Fogorvosi szemle, 1977; 70(4): 117-123.

43. Vámos I, Orosz M, Gábris K, Csiba A: [Incidence and distribution of tumors of the mouth cavity. 30 year's experience at the Clinic of Maxillofacial Surgery, Budapest]. Stomatol DDR, 1978; 28(10): 727-732

44. WARNAKULASURIYA KA, JOHNSON NW: Strengths and weaknesses of screening programmes for oral malignancies and potentially malignant lesions. Eur J Cancer Prev, 1996; 5(2): 93-98.

45. WARNAKULASURIYA S: Global epidemiology of oral and oropharyngeal cancer. Oral Oncol, 2009; 45(4-5): 309-316.

46. Warnakulasuriya S, Johnson NW, van der WaAl I: Nomenclature and classification of potentially malignant disorders of the oral mucosa. J Oral Pathol Med, 2007; 36(10): 575-580.

47. WHO: Application of international classification of diseases to dentistry and stomatology. Geneva 1978.

48. WHO: Cancer prevention and control. World Health Assembly. Geneva 2005.

49. WHO: Oral health: action plan for promotion and integrated disease prevention Geneva 2007 
Sonkodi I, Nagy J, Novák P, Braunitzer G, Virág K, Boda K, Nagy K

\section{A retrospective screening and epidemiological study of oncological and other diseases in the oral and maxillofacial region at the University of Szeged, Department of Oral Medicine \\ (1960-2014)}

The Department of Oral Medicine at the University of Szeged was responsible for the stomato-oncological care of the population of three counties (with a population of 1,7 M at an average) in the period 1960-2014. The present report summarizes the incidence of oral medicine diseases during this period. The overall number of new out-patients at the Department of Oral Surgery between 1960 and 2014 was 338,200. These patients were dental and oral surgical patients who presented spontaneously or were referred from the general practice, or stomato-oncological patients referred from general dental practices in the three counties. Of the 338,200 new cases, 9,482 (2.8\%) were benign tumors, $5438(1.6 \%)$ premalignancies and 5,145 (1.5\%) malignant tumors. This means a total of 20,065 tumor cases $(5.9 \%)$ in the examined period, of which 10,579 (3.1\%) were premalignancies and malignancies. 14,446 patients presented with other diseases of the oral mucous membrane (5.8\%, data available from 1974). Data on the number of stomato-oncological control patients in any given year are available from 1970 on. In the period 1970-2014, the total number of check-up patients was 117,268 , this is the $76,97 \%$ of the departments overall number of patients.

As for the tendencies, in the representative period of 1960-2004, the number of new benign tumors 15-fold, premalignancies 30-fold, and malignant tumors exhibited an 25-fold increase, while the number of other conditions affecting the oral mucosa showed a 14 -fold increase.

Keywords: oral medicine, stomato-oncology, incidence, Southern Hungary 